\title{
The making of a hybrid body: Corpus Christi in Lisbon, 1582
}

\author{
Elsje van Kessel
}

\begin{tabular}{|c|c|}
\hline Date of deposit & 14052019 \\
\hline Document version & Author's accepted manuscript \\
\hline Access rights & $\begin{array}{l}\text { Copyright (c) } 2019 \text { The Society for Renaissance Studies and John } \\
\text { Wiley \& Sons Ltd. This work is made available online in } \\
\text { accordance with the publisher's policies. This is the author } \\
\text { created, accepted version manuscript following peer review and } \\
\text { may differ slightly from the final published version. }\end{array}$ \\
\hline $\begin{array}{l}\text { Citation for } \\
\text { published version }\end{array}$ & $\begin{array}{l}\text { van Kessel, E. (2019). The making of a hybrid body: Corpus } \\
\text { Christi in Lisbon, 1582. Renaissance Studies, Early View. }\end{array}$ \\
\hline $\begin{array}{l}\text { Link to published } \\
\text { version }\end{array}$ & https://doi.org/10.1111/rest. 12590 \\
\hline
\end{tabular}

Full metadata for this item is available in St Andrews Research

Repository at: https://research-repository.st-andrews.ac.uk/

\section{St Andrews Research Repository}




\section{The Making of A Hybrid Body: Corpus Christi in LiSbon, 1582}

In Renaissance Lisbon, the procession of Corpus Christi was not only the most important event on the liturgical calendar but also one of the largest collectively produced works of art. This article argues that, in order to understand this complex, multi-layered artwork, it is necessary to move beyond such categorical opposites as 'local vs. other', 'artist vs. viewer' and even 'people vs. things', and instead approach these processions as a certain kind of hybrid. Focussing on a publication that recounts the Corpus Christi procession of September 1582, held to coincide with King Philip II of Spain's residency in Lisbon, the first part of the article examines the diverse artistic origins of elements of the procession, which included highly decorated streets, music, dances, and countless figures of saints and demons, demonstrating that renaissance Lisbon was a hybrid space. The second part of the article asks how this hybridity can be studied when art historical concepts and methods developed for canonical European art do not easily apply. It instead proposes an anthropologically-inspired framework that defines Lisbon's Corpus Christi as a networked hybrid of things, humans, and ideas.

Keywords: Corpus Christi, Lisbon, Hybridity, Iberian World, Spectacle.

On various locations in the city and on a range of occasions, people could encounter art objects in the streets of Renaissance Lisbon. A particularly fertile example is the series of processions held annually in celebration of the feast of Corpus Christi, during which streets and buildings on the route would be decorated with carpets, tapestries and flowers, and the processions would incorporate objects such as figures of giants and dragons. While these processions have received scholarly attention, as multi-layered artworks they need further 
analysis. In what forms and constellations did objects figure in Corpus Christi processions, and how did participants and viewers interact with them? One can only begin to answer this question meaningfully when moving beyond such categorical opposites as 'local vs. other', 'artist vs. viewer' and even 'people vs. things'. In other words, I suggest approaching these processions as a certain kind of hybrid. This article will analyse the artistic hybridity of Lisbon Corpus Christi processions, focusing on one specific publication recording the festival of 1582 . In so doing my article will open up the notion of hybridity to encompass not only matters of form but also of use and display - following David Summers, who sees the use of works of art as integral to world art history. ${ }^{1}$ In its understanding of hybridity in this sense it will find inspiration in developments in anthropology of recent decades, and particularly the tendency to question the divide between the living and the non-living in terms of agency. ${ }^{2}$ In so doing, the article will also align itself with recent work on hybridity in art history, and especially a number of compelling interdisciplinary studies on colonial Latin American art. ${ }^{3}$ Corpus Christi in the Iberian world in general, and in Lisbon in particular, was the most important celebration on the liturgical calendar and throughout the early modern period

\footnotetext{
${ }^{1}$ David Summers, Real Spaces: World Art History and the Rise of Western Modernism (London: Phaidon Press, 2003), passim.

${ }^{2}$ See, among others, David Grusin (ed.), The Nonhuman Turn (Minneapolis: University of Minnesota Press, 2015); Alfred Gell, Art and Agency: An Anthropological Theory (Oxford: Oxford University Press, 1998); Bruno Latour, We Have Never Been Modern (Cambridge, MA.: Harvard University Press, 1993).

${ }^{3}$ For instance: Barbara Mundy, The Death of Aztec Tenochtitlan, The Life of Mexico City (Austin: University of Texas Press, 2015); Barbary Mundy and Aaron Hyman, 'Out of the Shadow of Vasari: Towards a New Model of the 'Artist' in Colonial Latin America', Colonial Latin American Review, 24 (2015), 283-317; Susan Verdi Webster, 'Vantage Points: Andeans and Europeans in the Construction of Colonial Quito', Colonial Latin American Review, 20 (2011), 303-30.
} 
a source of continued civic pride. ${ }^{4}$ The focus of this article is on the procession held on 2 September 1582, organised in conjunction with the stay in Lisbon of King Philip II, who had recently been crowned Philip I of Portugal. This study thereby builds on a body of Portuguese scholarship on Corpus Christi that embeds the feast within the country's festival culture and the ephemeral arts more broadly. ${ }^{5}$ I will also make use of a growing body of work on the urbanism of Renaissance Lisbon. ${ }^{6}$ One of the crucial underlying premises of this text is,

\footnotetext{
${ }^{4}$ An important source for the status of Corpus Christi in Portugal is Inácio Barbosa de Machado's História Critico-Cronologica de Instituiçam da Festa, Procissam, e Officio do Corpo Santissimo de Christo no Veneravel
} Sacramento da Eucharistia (Lisbon: na Officina Patriarcal de Francisco Luiz Ameno, 1759).

${ }^{5}$ See, among others, Maria João P. Ferreira, Os têxteis chineses em Portugal nas opções decorativas sacras de aparato (séculos XVI-XVIII) Ph.D. thesis Universidade do Porto, 2011; Teresa Leonor M. Vale et al. (eds.), Lisboa e a festa: Celebrações religiosas e civis na cidade medieval e moderna (Lisbon: Câmara Municipal, 2009); Ana Paula Torres Megiani, O rei ausente: Festa e cultura política nas visitas dos Filipes a Portugal, 1581 e 1619 (São Paulo: Alameda, 2004); José Pedro Paiva, 'As festas de corte em Portugal no período Filipino’, Revista de História da Sociedade e da Cultura, 2 (2002), 11-38; João Castel-Branco Pereira et al. (eds.), A arte efémera em Portugal (Lisbon: Museu Calouste Gulbenkian, 2000); José Manuel Alves Tedim, Festa régia no tempo de D. João V: Poder, Espectáculo, Arte Efémera, Ph.D. thesis Universidade Portucalense Infante D. Henrique, 1999.

${ }^{6}$ Annemarie Jordan Gschwend and Kate Lowe (eds.), The Global City: Lisbon in the Renaissance (Lisbon: Museu Nacional de Arte Antiga, 2017); Annemarie Jordan Gschwend and Kate Lowe (eds.), The Global City: On the Streets of Renaissance Lisbon (London: Paul Holberton, 2015); Maria Helena Barreiros, 'Urban Landscape: Houses, Streets and Squares of 18th Century Lisbon', Journal of Early Modern History, 12 (2008), 205-32; Nuno Senos, O Paço da Ribeira (Lisbon: Notícias, 2002); Helder Carita, Lisboa Manuelina e a Formação de Modelos Urbanísticos da Época Moderna (1495-1521) (Lisbon: Livros Horizonte, 1999); Renata de Araújo, Lisboa: A cidade e o espectáculo na época dos descobrimentos (Lisbon: Livros Horizonte, 1990); Maria Eugénia Reis Gomes, Contribuição para o estudo da festa em Lisboa no antigo regime (Lisbon: Centro de Estudos de História e Cultura Portuguesa, 1985); Lisboa Quinhentista: A Imagem e a Vida da Cidade (Lisbon: Direcção dos Serviços Culturais da Câmara Municipal de Lisboa, 1983). 
however, that Corpus Christi in the capital of the Portuguese empire can only be understood from a European, and indeed global, perspective. ${ }^{7}$ The processions were part of an Iberian festival culture that encompassed not only Portugal and Spain but also the Americas and Asia. This is a fruitful field of investigation and I will refer here to the important work done by scholars like Fernando Checa Cremades, Laura Fernández-González, Teófilo Ruiz, and others, who have revealed much about the artistic forms, meanings, and political import of Iberian festivals. ${ }^{8}$ I hope to contribute to this on several levels: this examination of the 1582 Corpus Christi procession will add another festival to the canon of Spanish-Portuguese Habsburg celebrations, as so far more attention has been given to Philip II of Spain's entry into Lisbon of 1581, as well as Philip III's entry in $1619 .{ }^{9}$ My investigation will reveal shared patterns, but will also draw out specificities to which, given that this is a religious festival, the label of 'Habsburg' may well not apply. Further, in relation to scholarship on the hybrid

\footnotetext{
${ }^{7}$ See Sanjay Subrahmanyam, 'Connected Histories: Notes towards a Reconfiguration of Early Modern Eurasia', Modern Asia Studies, 31 (1997), 735-62; idem, 'Holding the World in Balance: The Connected Histories of the Iberian Overseas Empires, 1500-1640', The American Historical Review, 112 (2007), 1359-85; see also Lia Markey, 'Connected Art Histories?: A Response to Sanjay Subrahmanyam’s Explorations in Connected History', Spanish Italy and the Iberian Americas: < $\underline{\text { http://siia.mcah.columbia.edu/article/connected-art-histories- }}$ response-sanjay-subrahmanyam\%E2\%80\%99s-explorations-connected-history> (accessed December 2017).

${ }^{8}$ Fernando Checa Cremades and Laura Fernández-González (eds.), Festival Culture in the World of the Spanish Habsburgs (Aldershot: Ashgate, 2015); Teofilo F. Ruiz, A King Travels: Festive Traditions in Late Medieval and Early Modern Spain (Princeton: Princeton University Press, 2012). On Corpus Christi specifically see Sabina de Cavi, 'Corpus Christi in Spanish Palermo: Two Baroque Apparati by Giacomo Amato for the Duke of Uceda (Viceroy of Sicily, 1687-1696)', in Checa and Fernández-González, Festival Culture, 219-41, with further bibliography on the origins of the feast and its celebration in Flanders, Italy, and Spanish America. ${ }^{9}$ Laura Fernández-González, 'Negotiating Terms: King Philip I of Portugal and the Ceremonial Entry of 1581 into Lisbon', in Checa and Fernández-González, Festival Culture, 87-113; George Kubler, Portuguese Plain Architecture: Between Spices and Diamonds: 1521-1706 (Middletown: Wesleyan University Press, 1972).
} 
festivals of the colonial Americas, this article will suggest that, as regards festival forms, the capital of the Portuguese empire was itself already a hybrid space. ${ }^{10}$

The particularities of the procession of September 1582 - not to be confused with the 'regular' one in June that Philip also witnessed, as we shall see - are disclosed in several textual sources, first Philip's letters to his daughters, and secondly an official, nearly 180-page record of the event written by the Spaniard Isidro Velázquez Salmantino (Fig. 1). ${ }^{11}$ This highly detailed account has not yet been the object of rigorous analysis, and the present article is the first to explore fully the potential of this rich source - whereby 'rich' refers both to the density of information, and to its author's focus on material wealth - by questioning the

\footnotetext{
${ }^{10}$ Lisa Voigt, Spectacular Wealth: The Festivals of Colonial South American Mining Towns (Austin: University of Texas Press, 2016); Liam Brockey (ed.), Portuguese Colonial Cities in the Early Modern World (Aldershot: Ashgate, 2008); Carolyn Dean, Inka Bodies and the Body of Christ: Corpus Christi in Colonial Cuzco, Peru (Durham: Duke University Press, 1999); István Jancsó and Iris Kantor (eds.), Festa: Cultura e sociabilidade na América Portuguesa, 2 vols. (São Paulo: Hucitec; Edusp; FAPESP; Imprensa Oficial, 2001). See also Peter Burke, who argues that Renaissance Europe was characterised by hybridity: Hybrid Renaissance: Culture, Language, Architecture (Budapest: Central European University Press, 2016); Jerry Brotton and Lisa Jardine, Global Interests: Renaissance Art between East and West (London: Reaktion, 2000); Carolyn Dean and Dana Leibsohn, 'Hybridity and its Discontents: Considering Visual Culture in Colonial Spanish America', Colonial Latin American Review, 12 (2003), 6.

${ }^{11}$ I thank Nuno Senos for introducing me to Portugal's Corpus Christi and to Philip's letters. Cartas para duas infantas meninas: Portugal na correspondência de D. Filipe I para as suas filhas (1581-1583), ed. Fernando
} Bouza Álvarez et al. (Lisbon: Dom Quixote, 1999), 161-2; Isidro Velázquez, La orden que setuиo enla solenne procession que hizieron los deuotos cofrades del sanctissimo Sacramento, de la iglesia de S. Iulian, en la ciudad de Lisboa, celebrando la festiuidad de su cofradia, Domingo, dos de Septiembre, de 1582 (Lisbon: Manuel de Lyra, 1582); a summary of the account was published in Portuguese in the eighteenth century: Joaquim Roberto da Sylva, Relaçam da solemne procissam do Corpo de Deos, que aos dous de setembro de 1582 fez a Irmandade do Santissimo Sacramento da Freguesia de S. Julião desta Cidade (Lisbon: Joseph Antonio da Sylva, 1731). See also Diogo Ramada Curto, A cultura política no tempo dos Filipes (1580-1640) (Lisbon: Edições 70, 2011$), 103$. 
relation between festival and the printed word. As Teófilo Ruiz and Lisa Voigt, among others, have shown, Iberian festival accounts served various agendas, and their relation to the festivals they pretend to record faithfully is not always straightforward. ${ }^{12}$ I will therefore approach Velázquez's elaborate textual evocation of the procession as a work in its own right.

The purpose of this article is ultimately twofold: firstly, to identify the hybrid nature of Lisbon's Corpus Christi; and secondly, to see how this material may help us to approach 'artistic hybridity' differently. 'Hybridity' in the history of art has, in recent years, appeared in a variety of different guises and with slightly different meanings. Among the first to introduce the concept into debates on Renaissance art was Claire Farago in 1994. Farago used the notion of 'fertile hybrid images' to denote a type of culturally complex object that does not weaken cultural authority, but produces an overflow of meanings, thereby giving rise to the multiplication of identity. ${ }^{13}$ Recently, an important contribution has been Alessandra Russo's concept of mestizaje, itself inspired by Serge Gruzinski’s idea of métissage. ${ }^{14}$ Russo does not see mestizo art purely in a formalist light, nor does she, in agreement with Farago, adhere to what she calls the 'pessimist' view of a colonial art that forcibly responds to the needs of the colonisers only. Rather, mestizo works of art in New Spain aimed, for and by all

\footnotetext{
${ }^{12}$ Ruiz, A King Travels; Voigt, Spectacular Wealth, 17-8 and 152-3; see also Curto, A cultura política, 104; Helen Watanabe-O’Kelly, 'The Early Modern Festival Book: Function and Form', in John R. Mulryne et al. (eds.), Europa Triumphans: Court and Civic Festivals in Early Modern Europe, Vol. I (Aldershot: Ashgate, 2003), 3-18.

${ }^{13}$ Claire Farago (ed.), Reframing the Renaissance: Visual Culture in Europe and Latin America, 1450-1650 (New Haven: Yale University Press, 1994), 12; see also Homi Bhabha, The Location of Culture (London: Routledge, 1994); Burke, Hybrid Renaissance.

${ }^{14}$ Alessandra Russo, The Untranslatable Image: A Mestizo History of the Arts in New Spain (Austin: University of Texas Press, 2014); Serge Gruzinski, The Mestizo Mind: The Intellectual Dynamics of Colonization and Globalization (London: Routledge, 2002).
} 
parties involved, to make sense of new realities brought about by the coming together of worlds. I will similarly approach the Corpus Christi procession not as a mere reflection of 'reality', but rather as an intervention in Portugal's place within a European and crosscontinental network. In my incorporation of both visible and invisible aspects of the feast, I follow the important insights on hybridity in the work of Carolyn Dean, Dana Leibsohn, and Susan Webster. ${ }^{15}$

The main political and religious message of early modern Corpus Christi processions is well established: as Edward Muir summarises it elegantly, they became 'one of the most important occasions to connect governmental authority to the supernatural power of the Eucharist'.${ }^{16}$ However, this only gets us so far in understanding these complex, multi-sensory, exciting events. In examining the possibilities for a wider understanding of hybridity, my aim is not to define a way of using and displaying art objects that is allegedly uniquely Portuguese. Yet we might inevitably conclude that many of the more traditional art historical questions and methodologies have been determined by art of the perceived centres of Europe, and in particular, Italy, where, at least since Vasari, the arts of painting, sculpture and architecture held pride of place. The applicability of these questions to festivals in Lisbon, so central to Portugal's artistic production, is limited as a consequence. Corpus Christi in Renaissance Lisbon, at the heart of a maritime empire, while also at the margins of most Anglo-American art historical narratives, will be taken as a particularly fruitful case study to investigate how we can study European art in a way that is more sensitive to its place in the

\footnotetext{
${ }^{15}$ Dean and Leibsohn, 'Hybridity and its Discontents'; Webster, 'Vantage Points'; see also Byron Hamann, 'The mirrors of “Las meninas": Cochineal, Silver, and Clay', Art Bulletin, 92 (2010), 8-35, and the responses to it that were part of the same 'Interventions'.

${ }^{16}$ Edward Muir, Ritual in Early Modern Europe (Cambridge: Cambridge University Press, 1997), 75.
} 
world: how European art came about through global interactions, and what kind of questions we might ask to analyse European art's networked condition.

\section{The Order of the Solemn Procession}

The procession of 1582 took place at a crucial moment for Lisbon and for Portugal. The unexpected death of King Sebastian I (1557-1578) in the battle of Alcácer-Quibir had unleashed a period of dynastic crisis that culminated in the designation of Philip II of Spain as King Philip I of Portugal by the Courts of Tomar in 1581 . This was partly the result of a four month military invasion led by the Duke of Alba in 1580, during which Alba's troops sacked the capital city, with devastating consequences. ${ }^{17}$ Not much later, Philip made his triumphal entry into Lisbon, where he was to stay for the next two years. ${ }^{18}$ Here he explored, according to some, the possibility of making Lisbon the semi-permanent seat of court, a decision that would have transformed Lisbon into the de facto capital of the Iberian empire. ${ }^{19}$ The procession was certainly meant to play a role in this political power play. ${ }^{20}$ This was also the time that Portuguese maritime expansion reached its zenith. Over the course of the fifteenth and sixteenth centuries, the Portuguese had opened up sea routes and established trading posts from present-day Brazil in the west to Japan in the east. Yet the ascent to the throne of the Habsburg monarch, and the violence that had preceded it, caused uncertainty. As the Venetian ambassadors Vincenzo Tron and Girolamo Lippomani pointed out in their report on Portugal in 1581 , the price level in the shops, among them those selling Asian wares, was excessively

\footnotetext{
${ }^{17}$ See Rafael Valladares, La conquista de Lisboa: Violencia militar y comunidad política en Portugal, 15781583 (Madrid: Marcial Pons Historia, 2008).

${ }^{18}$ For a comprehensive analysis of the triumphal entry, see Fernández-González, 'Negotiating Terms'.

${ }^{19}$ Megiani, O rei ausente, 53-79.

${ }^{20}$ Curto, A cultura política, 102-6.
} 
high, due to the plundering that had taken place, and no ship from India had returned for two years. ${ }^{21}$ Such problems around intercontinental commerce and trade are relevant here, given that Corpus Christi was a feast with a strong imperial significance: it celebrated the triumph of the Catholic church in all corners of the globe. ${ }^{22}$

What did this particular version of the procession entail, according to the festival booklet? Isidro Velázquez, who described himself as a courtier from Salamanca, reports in his elaborate account that no expense was spared..$^{23}$ The festivities began on the night of 1 September, when the main streets of the procession were already decorated with some thirty painted and textile-clad arches and the start of the celebrations was marked with fireworks and music. The next morning, Velázquez wrote, the streets were full of people, some of whom had travelled from afar, and the route of the procession was lavishly decorated with a great variety of textile hangings. The king and his family witnessed the proceedings from a window at the back of the royal palace that overlooked Lisbon's main commercial street, the Rua Nova dos Mercadores. After the celebration of mass, the procession opened with a group

21 'Commentarii per Italia, Francia, Spagna e Portogallo overo relazione del viaggio de Signori Cavalieri Tron e Lippomani...', Biblioteca da Ajuda, MS 46-IX-5, fol. 263r; for Tron and Lippomani see also Kate Lowe, 'Foreign Descriptions of the Global City: Renaissance Lisbon from the Outside', in Lowe and Jordan, The Global City, 36-55. For the decline of the Portuguese empire in Asia in this period see Ernst van Veen, Decay or Defeat? An Inquiry into the Portuguese Decline in Asia 1580-1645, PhD thesis Leiden University, 2000; Manuel Lobato, Política e comércio dos Portugueses na Insulíndia: Malaca e as Molucas de 1575 a 1605 (Macau: Instituto Português do Oriente, 1999); Sanjay Subrahmanyam, The Portuguese Empire in Asia, 1500-1700: A Political and Economic History (London: Longman, 1993).

${ }^{22}$ Beatriz Catão Cruz Santos, 'Unidade e diversidade através da festa de Corpus Christi', in Jancsó and Kantor, Festa, vol. 2, 521-44; Dean, Inka Bodies.

${ }^{23}$ Nicolás Antonio, Bibliotheca Hispana Nova sive hispanorum scriptorum qui ab anno MD ad MDCLXXXIV floruere notitia (Madrid: apud Joachimum de Ibarra, 1783), 828. See also Velázquez’s description of Philip’s royal entry into Portugal. 
of musicians playing a variety of instruments, followed by clerics representing all the city's parishes and its religious confraternities. As was common in Portuguese Corpo de Deus celebrations, the clerics were succeeded by a crowd of dancers and musicians who performed wild, pagan dances. ${ }^{24}$ After the dances came the demons or fallen angels, an element of the procession singled out by Philip in his letters to his daughters, which were succeeded by the archangels and nine angelic choirs. The long remainder of the procession consisted of sacred elements representing key figures and stories from the Old and New Testaments: three carts with sculptures and paintings, and between them representations of a large number of saints Velázquez seems to be deliberately vague whether these were human actors, sculptures, or a combination of both. The procession naturally culminated in the sacred host, carried in a custodia under a lavishly decorated baldachin. Thus, it communicated Corpus Christi's essential message: the triumph of the Catholic faith. ${ }^{25}$

The procession was initiated and financed by the Confraternity of the Holy Sacrament, who were connected to the church of São Julião, located in the freguesia (neighbourhood) of the same name, which was also the seat of the royal palace. As such it was one of the countless events held most years in the wake of the 'universal' procession that took place on Corpus Christi day in May or June, and in which all the artisans of the city participated. ${ }^{26}$ Velázquez suggests, however, that the confraternity had interrupted its processions during the war of succession, and held its 1582 event to please the king and his sister, the Empress Maria of Austria (1528-1603). He also lists the confraternity's administrators, and those primarily responsible for the procession, by name: Rui Brandão, a nobleman, 'hidalgo dela casa del

\footnotetext{
${ }^{24}$ Velázquez, La orden, 18r-v.

${ }^{25}$ Dean, Inka Bodies; Curto, A Cultura Política, 102-6; Ruiz, A King Travels, especially 283-4.

${ }^{26}$ Giovanni Battista Confalonieri, Grandezza et magnificenza della città di Lisbona (1593-1596), ed. Alessandro Dell'Aira (Rovereto: Nicolodi, 2005), 216.
} 
Rey' and knight of the Order of Christ, the confraternity’s president; João de Escobar, potentially identifiable with the comic poet and musician of the same name; 'Iacome Fixeris' from Flanders; and others whose names are less distinctive ${ }^{27}$ Crucially, the administrators had the honour of paying for the procession out of their own pockets: the confraternity's funds were left untouched as a matter of principle. ${ }^{28}$ In the sixteenth century, it was the Câmara of the city of Lisbon that normally controlled the processions, but this was often an aspiration rather than a reality, and the processions depended on the contributions of many: the carts with biblical mysteries and other more outlandish figures were usually provided by the various guilds, while the façade decorations depended on the many inhabitants of the buildings on the route. ${ }^{29}$

In terms of the artists responsible, the history of Corpus Christi in this period is one of anonymity. The most specific attribution of any of the 1582 artworks Velázquez gives to the goldsmiths' guild, who produced the many figures of saints as well as the demons. ${ }^{30}$ Indeed, rather than being the product of a few named artists, Corpus Christi can be said to have been the work of the whole community. In the 'universal' procession on Corpus Christi day, the carts, monsters, giants and other imaginative figures that preceded the holy sacrament were produced by all of Lisbon's guilds. ${ }^{31}$ The many local processions that followed the main event

\footnotetext{
${ }^{27}$ Velázquez, La orden, 9r-12v. For Escobar see Teófilo Braga, Historia do theatro portuguez: A Comedia classica e as tragicomedias. Seculos XVI-XVII, Vol. 2 (Porto: Imprensa Portugueza, 1870), 212.

${ }^{28}$ Velázquez, La orden, 10v.

${ }^{29}$ See Confalonieri, Grandezza, 216-20 and 232-4; and Eduardo Freire de Oliveira, Elementos para a História do Município de Lisboa, 17 vols. (Lisbon: Typographia Universal, 1882-1911), Vol. 1, 421-9.

${ }^{30}$ Velázquez, La orden, $8 \mathrm{r}$ and 18v. This is not exceptional, however: as George Kubler argued in his seminal book on Portuguese architecture in the sixteenth and seventeenth centuries, the country's architectural history shares this characteristic: Kubler, Portuguese Plain Architecture, 7.

${ }^{31}$ Oliveira, Elementos, Vol. 1, 428-9.
} 
in the annual calendar, of which the procession held for Philip II is an example as we have seen, were productions of the parishes and the neighbourhood and thus, taken together, again engaged all the city. The implications of this collective process will be further examined below.

\section{Multiple Origins}

The preceding overview is the starting point of my analysis. While it helps us to understand certain peculiarities of the 1582 version, I have not sketched this historical-political context to suggest Lisbon's Corpus Christi can be reduced to it; indeed, we should be aware of the ways the feast resisted such instrumentalization. The first step of my investigation must be to address the materials, styles, and iconographies of the procession in relation to their real and perceived places of origin. Hybridity as a blending together of distinct artistic traditions within a single work of art is the guiding principle here.

Was there anything about the Lisbon's Corpus Christi that can be defined as local? Arguably the decision to present the king and his family with a Corpus Christi procession can be seen as specifically Portuguese. As mentioned above, the feast was a great source of pride to the country's inhabitants and foreign visitors highlighted Portugal's love of processions, Corpus Christi prime among them. ${ }^{32}$ Specific elements of the procession, such as the so-called folia and other dances at the procession's beginning, may also have been considered as local rather than universal. It is noteworthy in this context that Velázquez's account virtually neglects these spectacles: his exhaustive report covers them in a single page. ${ }^{33}$ Authorities, participants and spectators alike considered the dances a crucial ingredient of the Corpus Christi tradition, if a much contested one. Giovanni Battista Confalonieri (1561-1648), who spent three years

\footnotetext{
${ }^{32}$ For a foreign view, see Confalonieri, Grandezza, 216.

${ }^{33}$ Velázquez, La orden, 18r-v.
} 
in Lisbon as secretary to Fabio Biondi, collettore and vice-legate of the Holy See, and who witnessed the procession on 9 June 1594, refers to them as an old tradition, and therefore difficult to eradicate. ${ }^{34}$ Apparently disapproving, Confalonieri seems to have been surprised by the ubiquity of these dances in Lisbon, and their presence in religious festivals specifically, although such dances were performed in some form all over the Iberian world and indeed also in Italy. The Lisbon authorities attempted to suppress these dances from time to time all the same, because of their unorthodox and potentially subversive nature ${ }^{35}$ Confalonieri lists a number of dances and related practices in his description of Lisbon's religiosity. He speaks of masked dances and of 'Moorish drums'. He lists other musical instruments, such as the 'chitarra spagnola', a 'vile instrument' according to the cleric, and 'black men who carry girls on their shoulders'. There were dances where white and black women mix, and dances of black women only. ${ }^{36}$ The dancers accompanied themselves with their instruments, not only drums but also tambourines. They also sang, in loud and high-pitched voices. ${ }^{37}$

Some impression of what this part of the procession looked like can be gained from Portuguese silverwork of the period, in particular a group of salvers. Take, for example, a silver salver (Fig. 2) with a broad decorated outer edge around a central panel with an enthroned king, now in the Metropolitan Museum. It shows, against a background of foliage from which figures seem to be appearing and disappearing at the same time, a frantic parade of wild folk, humans and animals, feverishly facing and tumbling over one another. Such

\footnotetext{
${ }^{34}$ Confalonieri, Grandezza, 216.

${ }^{35}$ João Pedro Ribeiro (ed.), Dissertações chronologicas e críticas sobre a História e Jurisprudencia ecclesiástica e civil de Portugal, 5 vols. (Lisbon: Academia Real das Sciencias, 1810-1836), Vol. 4, part II, 199201; see also Oliveira, Elementos, Vol. 11, 193.

${ }^{36}$ The racial politics of Portugal's Corpus Christi tradition are in need of further research; see José Ramos Tinhorão, Os negros em Portugal: uma presença silenciosa (Lisboa: Caminho, 1988), 154 and further.

${ }^{37}$ Confalonieri, Grandezza, 216-7; Cartas para duas infantas meninas, 154.
} 
decorations reflect motifs from the country's Corpus Christi. ${ }^{38}$ Used in the nobility's ritual of the tasting of the wine, such salvers and their decorations had Eucharistic connotations, while also inviting associations with the ecstatic, pagan, Dionysian. The three-volume reference work A Arte Popular em Portugal, published in the later years of António Salazar's dictatorship and itself an object worthy of scholarly scrutiny, contains photographs of some of the Corpus Christi dances taken in the Portuguese provinces. ${ }^{39}$ One such illustration shows a group of costumed men armed with long sticks perform a carefully choreographed martial ritual called the 'dance of the swords' (Fig. 3). ${ }^{40}$

Confalonieri not merely records, but also makes an attempt to interpret what he sees. He displays a proto-ethnographic attitude towards the various types of dances, most notably the folia and the pella. He connects both of them with a certain spirited madness, as in the games for the goddess Pallas in classical Greece, while also implying relations between eastern and western traditions of music making. ${ }^{41}$ This interpretation is especially revealing of Confalonieri's own background: as an Italian humanist, he aimed to locate the cultural origins of the dances in the classical past. And he was not alone in his attempt to determine the cultural origins of what to many foreigners was an unusual practice in this religious context. His compatriot Filippo Sassetti, who likewise spent some years in Lisbon, devoted some attention to them in a letter to Florence. He mentions the 'craziness' of the female dancers, and hints at their state of inebriation, subsequently pondering the alleged origins of the dances

\footnotetext{
${ }^{38}$ Maria Leonor Borges de Sousa d'Orey (ed.), Inventário do Museu Nacional de Arte Antiga: A colecção de ourivesaria (Lisbon: Instituto Português dos Museus, 1995), 140-55. I thank Luisa Penalva for directing me towards this object.

${ }^{39}$ Fernando de Castro Pires de Lima (ed.), A Arte Popular em Portugal, 3 vols. (Lisbon: Verbo, [1963]).

${ }^{40}$ Ibid., 312-3.

${ }^{41}$ Confalonieri, Grandezza, 218-9.
} 
in Moorish costumes. ${ }^{42}$ Castilian onlookers in turn were baffled particularly by the music and, despite the close proximity between the Portuguese and Castilian language, claimed the songs were impossible to understand. ${ }^{43}$ One is faced here with the paradoxical situation that, on the one hand, the folia and other dances were regarded as a uniquely local element of Corpus Christi, and on the other hand that foreign witnesses sought their origins outside of the country in the cultures of northern Africa and ancient Greece. With their general observation that these typical dances themselves were already a mélange of different traditions, we can still agree. ${ }^{44}$

There are other elements with evident foreign origins. The twelve demons that followed the dances are a case in point. These seem to be the part that made the greatest impression on Philip, as he writes, in a letter to his daughters:

Even though they had told me much about it, I did not expect [the procession] would look so good to me, and it looked even better than everyone was expecting. I am very sorry that you haven't seen it, nor your brother, although there were some devils that looked like the paintings of Hieronymus Bosch, of which, I think, he would have been afraid. ${ }^{45}$

\footnotetext{
${ }^{42}$ Filippo Sassetti, Lettere da vari paesi: 1570-1588, ed. Vanni Bramanti (Milan: Longanesi, 1970), 232-3.

${ }^{43}$ Cartas para duas infantas meninas, 154.

${ }^{44}$ See Gruzinski, The Mestizo Mind.

${ }^{45}$ Cartas para duas infantas meninas, 161-2.
} 
While this passage has some renown among specialists, its implications have, to my knowledge, never been examined in depth. ${ }^{46}$ There is a further, albeit indirect, indication that Bosch's art was a source for these figures. Velázquez posits that the goldsmiths paid and created them, based on a 'panel with the temptations of St Anthony'. ${ }^{47}$ The temptations of St Anthony, where the hermit saint is besieged by demons, was a popular subject in sixteenthcentury Netherlandish art, and an important one in Bosch's oeuvre. ${ }^{48}$ Portuguese collectors like the humanist Damião de Góis owned a sufficient number of paintings by Bosch and his followers that his characteristic demonic figures could have served the goldsmiths' guild as models (Fig. 4). ${ }^{49}$ Netherlandish artists regularly worked in Lisbon, and their painting was a key influence on Portuguese art, so much so that Francisco de Holanda in his 1548 art treatise famously let Michelangelo burn Netherlandish painting to the ground as an art for "women

\footnotetext{
${ }^{46}$ Fernando Checa, 'The Fire and the Owl: On the Reception of Bosch's Work by the Spanish and Flemish Habsburg Courts in the Sixteenth Century', in Pilar Silva Maroto (ed.), Bosch: The $5^{\text {th }}$ Centenary Exhibition (London: Thames and Hudson, 2016), 156-71.

47 ،... alguna tabla de las tentaciones de sancto Anton...’ Velázquez, La orden, 18v.

${ }^{48}$ To be sure, the hypothetical panel to which Velázquez refers cannot be Bosch's famous Triptych of St Anthony currently in Lisbon: this work only reached Portugal in the later nineteenth century. Joaquim Oliveira Caetano, 'A Historical Survey of Lisbon's Bosch', in Jo Timmermans (ed.), Jheronimus Bosch, his Patrons, and his Public ('s-Hertogenbosch: Jheronimus Bosch Art Center, 2014), 72-83. The panel illustrated here is a copy of the Lisbon original. J. Bogers, 'Copy after Jheronimus Bosch, The Temptation of St Antony, c. 1530 - c. 1600', in J.P. Filedt Kok (ed.), Early Netherlandish Paintings, online coll. cat. (Amsterdam: Rijksmuseum, 2010): hdl.handle.net/10934/RM0001.COLLECT.6189 (accessed 16 April 2019).

${ }^{49}$ Pilar Silva Maroto (ed.), Bosch: The $5^{\text {th }}$ Centenary Exhibition (London: Thames and Hudson, 2016), cat. no. 23 (entry by Joaquim Oliveira Caetano), 238-45. For the illustrated painting, see Matthijs Ilsink et al., Hieronymus Bosch, Painter and Draughtsman: Catalogue Raisonné (Brussels: Mercatorfonds, 2016), cat. 30, $452-4$.
} 
and old people' ${ }^{50}$ Also in the later sixteenth century its popularity remained. As in the case of the dances, however, the question is whether the Boschian demons were perceived as having a single origin. Were these demons seen to be 'Netherlandish'? Complicating the picture is the great love for Bosch at the Habsburg courts, and the fact that the young Philip's first acquaintance with Bosch during his stays in Flanders ignited a lifelong passion; as king he became a great collector of the artist's work. ${ }^{51}$ While there is no evidence of direct royal intervention of the procession, it is not unlikely that the organisers knew of the king's taste, and used elements that were also part of Lisbon's own visual culture to please him. ${ }^{52}$ The figures of the demons could therefore also have had a certain Habsburg flavour.

Another source for the procession in an iconographic, stylistic and material sense was Portugal's large Asian empire. Velázquez points to the Indian and Chinese origins of some of the clothing and accessories worn by saintly figures, such as King David, who donned 'oriental' emeralds, an Indian fan, and a harp made of Chinese lacquer. ${ }^{53}$ In reality, there must have been many more Asian elements in the procession, given the frequent use of IndoPortuguese and Sino-Portuguese textiles in religious festivities. As Maria João Ferreira, who has studied this phenomenon in depth, points out, the use of such 'pagan' objects in the Catholic rite was religiously and politically motivated. ${ }^{54}$ For example, the silk damask

\footnotetext{
${ }^{50}$ Francisco de Holanda, On Antique Painting, translated by Alice Sedgwick Wohl (University Park, PA: Pennsylvania State University Press, 2013), 179-80.

${ }^{51}$ Checa, 'The Fire and the Owl'.

${ }^{52}$ For the involvement of royal designers in Philip's entry into Lisbon in 1581, see Fernández-González,

'Negotiating terms'.

${ }^{53}$ Velázquez, La orden, 66r.

${ }^{54}$ Ferreira, Os têxteis chineses; idem, 'Political Intentions of Chinese Textiles in Portuguese Sacred, Solemn, Celebratory Events of the 16th-18th Centuries', in Textiles and Politics: Textile Society of America $13^{\text {th }}$ Biennial Symposium Proceedings, UNL Digital Commons, 2012: < http://digitalcommons.unl.edu/tsaconf/682/>
} 
decorated with elephants, flowers, and double-headed eagles traded through Macao (Fig. 5) and specifically made for the Iberian market would, with its gold and deep blue shine, have evoked the paradisiacal Garden of Eden. At the same time, on a more mundane level, it would have communicated to the people in the metropole the worldwide spread of the Catholic faith.

Evidently the Corpus Christi procession of 1582 drew from artistic traditions from various areas in Europe and elsewhere in the world. This variety was noted and discussed by various contemporary witnesses. In addition, the Habsburgs attempted to appropriate Lisbon's Corpus Christi, together with its evident multiplicity of sources, as specifically Spanish: in the opening words of his account, Velázquez describes the city's tradition as a 'praiseworthy custom of Spanish Christendom', pointing to the intention behind his account as a whole to incorporate Lisbon's feast into the rich festive culture of the Habsburg empire. ${ }^{55}$ Combining all these distinct artistic traditions, Corpus Christi can be defined as a hybrid.

\section{Towards a Networked Corpus Christi}

It is one thing to classify a work of art as artistically hybrid, but it is quite another to achieve a full comprehension of the work in question. Hybridity and the many terms that are often used as near synonyms, such as combination, mixture, mestizo, mélange, and syncretism, are descriptive labels that in themselves have little explanatory value. They often merely serve to describe a situation of great complexity and chaos where one thing merges with another and borders are unclear. ${ }^{56}$ This merging may be more or less politically fraught. ${ }^{57}$ As Gruzinski

\footnotetext{
(accessed August 2017); idem, 'Asian Textiles in the "Carreira da Índia": Portuguese Trade, Consumption and Taste, 1500-1700', Textile History, 46 (2015), 147-68.

${ }^{55}$ Velázquez, La orden, 9r.

${ }^{56}$ See Gruzinski, The Mestizo Mind, Chapter 2.

${ }^{57}$ See Dean and Leibsohn, 'Hybridity and its Discontents'.
} 
points out, analysing hybridity is fundamentally problematic, not simply because it requires a different approach or wide knowledge of a great variety of artistic expressions, but because analysis in itself means taking things apart to study them in isolation, so that one risks losing sight of what makes hybridity distinctive. ${ }^{58}$ How, then, to understand the hybridity of a work of art like Lisbon's Corpus Christi? This article does not pretend to present a solution to this problem, which I would argue is one of the most pressing ones in Renaissance art history today. The only thing I can do within the confines of this article is to ask questions about, and signal problems around, a number of key presuppositions that originated in the historiography of European art, in order to suggest that new frameworks are needed with which to approach artistic hybridity. Recent successful studies of Latin American colonial art thereby serve as an example, yet the point I want to make here is that the hybridity of European, and especially Iberian, art needs further attention as well, as a focus on the hybridity of colonial spaces risks the homogenisation of the colonial centre. ${ }^{59}$

The first of these is the idea that the work of art communicates a message that can be 'read', as one distils meaning from a text. My point is not to deny that such meaning exists; rather, I suggest that it only takes us so far. In terms of the iconography of Corpus Christi, the most helpful source is, indeed, a text. Velázquez's account contains many pointers, as it painstakingly takes the reader through the history of salvation, from the Old Covenant to the New Covenant and the history of the Church. But, as we have seen, the saintly figures and the carts with religious mysteries only made up a part of the totality of the feast. The meaning of the 'inventions', the monster figures and the dances, deliberately downplayed by Velázquez,

\footnotetext{
${ }^{58}$ Gruzinski, The Mestizo Mind, 26-7. Dean and Leibsohn (as above) point out that hybridity relies on a notion of purity, and requires discrimination.

${ }^{59}$ Dean and Leibsohn, 'Hybridity and its Discontents', 6.
} 
is harder to pin down, given also their frequent re-use in other festive contexts. ${ }^{60}$ Similarly, Velázquez's own extensive descriptions of the clothes and jewellery worn by the procession's many saintly figures appear elusive if addressed in terms of iconography. His apparently endless, highly evocative descriptions of outfits and accessories go beyond signification in trying to evoke, within the constraints of the text, the shine of silk and the opulence of pearls and stones.

King Philip himself underlined this problem of the limitations of language. On the eve of the procession, he received a memorandum that aimed to explain all the vernacular elements. ${ }^{61}$ As Philip confessed to his daughters, to whom he forwarded the memorandum, he did not understand everything in the procession, nor in the document, as it was written in Portuguese rather than Castilian. ${ }^{62}$ Most tellingly, he admits that his daughters' comprehension of the procession of necessity will have its limits, as 'between what is seen and what is written there is a large difference'. ${ }^{63}$ In Philip's pondering we hear an echo of the impossibility of encompassing everything about the procession through words alone. ${ }^{64}$

Looking at Lisbon's Corpus Christi, a more traditional quest for its meaning fails to help us understand the complexity of the feast. To borrow a phrase from Hans Ulrich Gumbrecht, there are elements of Corpus Christi 'which meaning cannot convey'. ${ }^{65}$

\footnotetext{
${ }^{60}$ Curto, A Cultura Política, 106; see also Oliveira, Elementos, Vol. 1, 430.

${ }^{61}$ Cartas para duas infantas meninas, 162-3; Velázquez, La orden, 15r.

${ }^{62}$ Cartas, 163. The original letters from Philip II to his daughters Isabel Clara Eugénia and Catarina Micaela are kept in the Archivio di Stato di Torino. Staff of the archive let me know that the paper mentioned by Philip could not be traced.

${ }^{63}$ Ibid., 162. See also Watanabe O’Kelly, 'The Early Modern Festival Book'.

${ }^{64}$ See also Ruiz, A King Travels, chapter 1.

${ }^{65}$ Hans Ulrich Gumbrecht, Production of Presence: What Meaning Cannot Convey (Stanford: Stanford University Press, 2004).
} 
According to Gumbrecht, 'meaning' is based on a dualistic, modern understanding of the world, in which mind and body, spiritual idea and material container are conceptually separate. While many academic fields are currently questioning the helpfulness of this subject-object divide, to abandon it is also historically sound, given that in sixteenth-century Lisbon, a Eucharistic worldview prevailed. ${ }^{66}$

A second supposition that Lisbon's Corpo de Deus - which was indeed the celebration of Christ's body, one with the host - compels us to question is the artwork as the material outcome of a single artist's mental process. Ever since Vasari this idea has dominated the study of European art, including the art of European colonies, and it has effectively side-lined other practices, including Italian ones, as allegedly 'ethnographic' or 'decorative'. ${ }^{67}$ While Corpus Christi is neither of these, it is not the product of a singular mind either. By contrast, a more helpful term with which to describe its making is 'collectivity'.

Indeed, the production of the ensemble of Corpus Christi processions brought Lisbon society together. Inhabitants of the buildings along the route were obliged to decorate their windows and balconies with precious textile hangings. Dwellers could even be fined if they failed to do so, or if their decorations were of too humble a quality. ${ }^{68}$ 'Dressing' one's home in the appropriate manner was a demonstration of devotion, and a way of sharing the enormous expense that the procession entailed. The distribution of such textiles occurred by means of various channels. As Ferreira has shown, they required collective labour and the

\footnotetext{
${ }^{66}$ Grusin, The Nonhuman Turn; for the Eucharist see also Gumbrecht, 'Epiphany of Form: On the Beauty of Team Sports', New Literary History, 30 (1999), 355-6.

${ }^{67}$ See Mundy and Hyman, 'Out of the Shadow of Vasari'.

${ }^{68}$ Ibid., 432.
} 
sharing of wealth: textiles would be leased and borrowed or made by groups of nuns in the city's convents; they therefore allowed for far-reaching participation of all layers of society. ${ }^{69}$

Furthermore, ethnic minority groups would - voluntarily or not - be involved in the dances. ${ }^{70}$ Guilds would produce carts with tableaux vivants and monsters. All the lay confraternities would walk with banners. The king, whoever he was, would also join in, walking behind the holy sacrament. ${ }^{71}$ Even Velázquez's account, although it does much to put a Spanish Habsburg stamp on Lisbon's feast, took part in this collectivity. Published in Lisbon by local publisher Manuel de Lira, it gives considerable attention to the Confraternity of the Holy Sacrament, which suggests that they may have been involved in its publication, for example through financial support. ${ }^{72}$

In conjunction with the collective character of Corpus Christi, the 'final product' - if such a thing exists - was not all that mattered. The making of Corpus Christi as a collective enterprise was arguably its main purpose. The production of the feast by the whole community was a performance that fabricated and refabricated society itself. For this reason, crucial elements of the procession needed to be made anew every liturgical cycle. The Lisbon processions were notorious for the enormous expense they brought upon the city and its inhabitants for this reason. ${ }^{73}$ Not unlike present-day Carnival celebrations in and beyond the

\footnotetext{
${ }^{69}$ Velázquez mentions that the brothers of São Julião borrowed jewels for similar reasons: Velázquez, La orden, 8v. Maria João P. Ferreira, 'O protagonismo dos têxteis nas celebrações realizadas em Lisboa por ocasião das canonizações de Santo Inácio de Loyola e São Francisco Xavier (1622)', in Vale, Lisboa e a festa, 165.

${ }^{70}$ About this important aspect of the festival's hybridity, see forthcoming work by Lisa Voigt on the participation of Africans and Amerindians in Portuguese festivals.

${ }^{71}$ In June 1582, Philip wrote to his children that he did not see much beyond the dances, because he himself had to join the end of the long procession: Cartas para duas infantas meninas, 154.

${ }^{72}$ See ibid. for comparison.

${ }^{73}$ Oliveira, Elementos, Vol. 1, 432; Confalonieri, Grandezza, 216.
} 
Portuguese-speaking world, continuous renewal for example by producing new carts and writing new music was one of Corpus Christi's attractions.

As a result of the importance of collective making, the standard art historical categories of 'artist' and 'viewer' are irrelevant in the case of Corpus Christi. In Corpo de Deus, everyone was a maker. Those who provided objects were, as were those who walked, played, or danced in the procession. Even those who watched from a window were participants. Tying this back to September 1582, staging a Corpus Christi procession for king Philip and his family was a way for the people of Lisbon to come to terms with the new political reality. Although Velázquez frames it entirely to serve Spanish Habsburg interests, this collective enterprise was also an assertion of the Lisbon people and an attempt to incorporate the new king into it. To understand this, we require a model of artistic production that looks at societies as a whole.

A final question I want to bring up regards the autonomy of the artwork. This article has deliberately and consistently referred to Lisbon's Corpus Christi as one multifaceted work of art. To study its various elements separately might lead to misinterpretations. But the procession also contradicts the notion of autonomy in a more radical way: it blurred the boundaries between lifeless objects and human participants.

A compelling illustration of this type of blending of humans and lifeless objects in Portuguese festival culture is the painting The Arrival of the Relics of St Auta at the Convent of Madre de Deus (Fig. 6), itself part of a larger whole, which shows a richly dressed female saint in front of a heavily decorated procession. All that is important in the scene is draped in precious textiles: the saint herself wears a red and gold brocade dress, which appears to be of the very same fabric that is used to protect her reliquary. The baldachin is again made of the same material, as are the copes and other pieces of liturgical clothing worn by the most important clerics. The altar placed at the entrance of the church is wrapped in this rich fabric, 
as is the Manueline architecture of the portal itself. In this way, the textile effectively erases the differences between buildings, saints, and humans. In Corpus Christi, rich textiles achieved a similar effect: draping architecture, clerics, saintly statues and the baldachin above the body of Christ, it brought together the city with all its human and nonhuman components.

The procession also gave a darker vision of such communion. The figures of the demons equally combined living and non-living forms, but in doing so they instilled fear. The first of the twelve, as a thrilled Velázquez tells us, had a gigantic, frightening face, hidden partly in a helmet, and his body was covered in scale-like armoury. He carried a belt made of fox hides and instead of hands and feet he had claws. On his arms, legs and back grew wings stained with grimy colours, and in his right hand he held a morning star with the punts in the form of fire. ${ }^{74}$ Many of these features reappeared in the other devils: a combination of human and animal forms, limbs in strange places, and body parts replaced by armoury. ${ }^{75} \mathrm{We}$ know such fantastical figures from Bosch's universe, and here they were taken from the twodimensional medium of painting to the three-dimensional, real space of the procession. It is precisely their blending together of usually distinct things - that is, their hybridity - that made them so entertaining and, potentially, fearful. Also in this instance, holding on to the idea of the artwork's autonomy is not helpful. Bosch's demonic figures take the blending together of the human, the animal, and the lifeless, which was in fact pervasive in sixteenth-century society, to an evil extreme. To come to terms with the role of the 'nonhuman' in the Corpus Christi procession, an approach is needed that goes beyond the modernist subject-object divide.

In regard to these problems - and they are all connected of course - anthropological approaches that attempt to redefine the relation between the living and the non-living may

\footnotetext{
${ }^{74}$ Velázquez, La orden, 18v-9r.

${ }^{75}$ Ibid., 19r-27v.
} 
have an important role to play. ${ }^{76}$ Bruno Latour's work on hybridity, which comes at the problem from a very different angle than the one explored in this special issue, has been crucial in breaking down the hierarchy in the humanities between things, humans and ideas. ${ }^{77}$ Alfred Gell's Art and Agency has helped us to think through the agency of works of art. ${ }^{78}$ These anthropological frameworks provide methodologies for studying hybrid communions of artworks and people in a non-hierarchical, networked setting. To do so is not to say that something is missing in the work of art; rather it is to acknowledge that the western work of art came about in an intercontinental context, and requires questions and methodologies that allow this to be fully understood. ${ }^{79}$

\section{Conclusion}

Lisbon's Corpus Christi in the sixteenth and seventeenth centuries was a complex, often contradictory, work of art. With Portugal at the margins of Eurocentric art historical discourse, methods and frameworks developed for what have long been seen as the main types of art of the heartland of that tradition do not easily apply to it. There are few artists' names; iconographic analysis is of limited relevance; nor is there a coherent sense of style. Tracing the origins of the many visual components of the Corpus Christi procession, it becomes clear that these are varied and often lie outside the country. Given the dominance of Corpus Christi in late medieval and early modern Portugal's religious and artistic life, it is safe to conclude that trying to understand Portuguese art in a nationalist framework is entirely

\footnotetext{
${ }^{76}$ See Grusin, The Non-Human Turn.

${ }^{77}$ Latour, We Have Never Been Modern.

${ }^{78}$ Gell, Art and Agency.

${ }^{79}$ See Christopher Wood, 'Image and Thing: A Modern Romance', Representations, 133 (2016), 130-51.
} 
unhelpful: sixteenth-century Portugal was at the centre of a European and global maritime network, and in Corpus Christi Portuguese people responded to this fact.

While studies of Latin American versions of the feast have singled out the ways it combined European Catholic and local elements, this article shows that also in the colonial metropole Corpus Christi was a hybrid. Vis-à-vis the mestizo art of the Spanish and Portuguese colonies, there is no such thing as the 'purity' of the European centre. Lisbon's Corpus Christi had a global dimension in the sense that it used materials, styles and iconographies from all over the Portuguese empire, but also in that it engaged all levels of society and different ethnic groups. When Portugal came under Habsburg rule, the procession was used to negotiate the power balance; but Philip II would have found many similarities between Lisbon's Corpus Christi and the version he knew from Spain. Its hybridity was not unlike the one that characterised the feast elsewhere.

If hybridity is indeed a defining feature of the early modern Iberian arts, then the next question is how best to analyse it. In the final part of this article I hope to have revealed some of the problems inherent in art historical ideas, and hinted at an alternative framework that describes Lisbon's Corpus Christi as a networked hybrid of things, humans, and ideas. There are several advantages to this way of looking: it allows us to see Corpus Christi as a process rather than fixed and unchanging; it brings to the fore the feast's communion of people and material culture, and it enables us to see the effects of disparate elements that seemingly lack meaning. While the scope of this article was necessarily limited to Lisbon's Corpus Christi in the late sixteenth century, its relevance goes beyond that extraordinary procession, and will, I hope, lead us to keep rethinking hybridity, so as to include anthropological interpretations of the term, regardless of the perceived origins of an object of study. 


\section{Captions}

Fig. 1 Isidro Velázquez, La orden que setuvo en la solenne procession que hizieron los devotos cofrades del Sanctissimo Sacramento... (Lisboa: Manuel de Lyra, 1582), Biblioteca Nacional de Portugal, Lisbon, title page [with permission of the Biblioteca Nacional de Portugal]

Fig. 2 Portugal, Dish, c. 1500-1520, silver-gilt, 3 x 26 cm, New York, Metropolitan Museum of Art [public domain]

Fig. 3 'The Dance of the Swords', from Fernando de Castro Pires de Lima (ed.), A Arte Popular em Portugal, 3 vols. (Lisboa: Editorial Verbo, [1963]), Vol. 2, 312 [with permission of Editorial Verbo]

Fig. 4 Copy after Hieronymus Bosch, The Temptation of St Anthony, c. 1530-1600, oil on panel, 68.7 x $86.9 \mathrm{~cm}$, Amsterdam, Rijksmuseum [public domain]

Fig. 5 China, Macao, for the Iberian market, Textile with elephants, crowned double headed eagles, and flowers, second half of the sixteenth century, silk damask, 189.2 x $73.7 \mathrm{~cm}, \mathrm{New}$ York, Metropolitan Museum of Art [public domain]

Fig. 6 Lisbon workshop, The Arrival of the Relics of St Auta at the Convent of Madre de Deus, c. 1522, oil on panel, 70.5 x 76 cm, Lisbon, Museu Nacional de Arte Antiga [@ José Pessoa, Direção-Geral do Património Cultural / Arquivo de Documentação Fotográfica (DGPC/ADF)] 


\section{Acknowledgements}

Research for this article was generously funded by the Investigação em Cultura Portuguesa programme of the Fundação Calouste Gulbenkian. I am grateful to CHAM - Centro de Humanidades for their hospitality during my months in Lisbon. Thank you, in particular, to João Paulo Oliveira e Costa and Nuno Senos for their encouragement and advice. A final word of thanks goes to the editors of this special issue, Laura Fernández-González and Holly Trusted, for their invaluable feedback and support. 